\title{
Italian Radicals in Tampa, Florida: A Research Note
}

\section{George E. Pozzetta}

University of Florida at Gainesville

Traditional library repositories have not, for the most part, assigned high priority to the collection and preservation of documentation bearing upon the history of the immigrant left. As a result, a great number of newspapers, organizational records, books, and pamphlets have been lost to the historical record. The official policies of the government have occasionally resulted in the further loss or destruction of valuable materials (the Palmer Raids are a prime example). The acquisition by research institutions of such materials, therefore, has become an all too rare event. This research note is to inform scholars investigating the history of the immigrant left of a recently acquired collection that may assist in their labors. The materials involved were donated to the Special Collections Department of the University of South Florida Library by the Italian Club of Tampa.

Italians were largely drawn to Tampa in the late 1880s by the lure of the city's burgeoning cigar industry. Once employed, they entered a trade that possessed a well deserved reputation for radical militancy. Italians soon structured for themselves a vigorous leftist subsociety that featured a wide spectrum of socialist, anarchist, and syndicalist activities. Indeed, as early as 1900 Tampa was fully integrated into the mainstream of the national and international radical world. The cigar city was a regular stopover on the giro di propaganda of visiting Italian and ItalianAmerican radical luminaries. Arturo Caroti, Luigi Galleani, and Errico Malatesta, to name a few, made visits to Tampa to lecture, hold public debates, and proselytize. Within the city itself, there existed Italian language radical newspapers, debating clubs, cigarmakers' unions, and leftist political parties. ${ }^{1}$ One noted scholar has described Tampa as "a major stronghold of foreign-born anarchists between 1890 and 1920, a kind of southern Paterson, New Jersey."2

The Italian Club of Tampa (L'Unione Italiana), founded in 1894, was the focal point of much of Italian immigrant life in the city. As such it was the spawning ground and often the meeting place for the various Italian radical groups that emerged in Tampa. Recently, the Club has given the contents of its library as well as a number of society records to the University of South Florida Library. Thirteen very large ledgers, for example, contain information on membership lists, dues payment schedules, and personal data of members (name, address, birthplace, 
etc.) covering the years 1901-1942. These records are most complete for the period after 1910.

The Club library constitutes the largest part of the collection. It consists of approximately two hundred volumes and assorted pamphlets, journals, and articles. The volumes range from well-known works of literature, including plays, poetry, novels, and short stories, to a handful of basic texts on English grammar, spelling, and mathematics. The works of many noted literary figures such as Emile Zola, Victor Hugo, Maxim Gorki, and Miguel de Cervantes are available in Italian and Spanish language editions. A large number of these works deal with the proletarian themes favored by workers.

The most interesting and rare part of the library is composed of a sizable collection of socialist and anarchist literature (listed below). There are Italian editions of the great masters--Peter Kropotkin, Michael Bakunin, Eliseo Réclus, Pierre-Joseph Proudhon, etc. A number of these volumes are found in handsome (and expensive) leather bound copies that are suggestive of the important place they occupied in the library's holdings. Italian propagandists are also found, with the particular favorites being Errico Malatesta, Armando Borghi, and Pietro Gori. Local authors, such as the Spanish anarchist Pedro Esteve found their way onto the library's shelves as well. Finally, there is a generous sampling of the sociological and political science brand of material that radical groups typically read as part of their autodidactic training (Ivanoe Bonomi, Edmondo de Amicis, Gaspare Nicotri, etc.). Individuals desiring further information on the Italian Club collection should address their inquiries to Paul E. Camp, Special Collections, University of South Florida Library, Tampa, Florida 33620.

NOTES

1. For more information see, George E. Pozzetta, "Immigrants and the Southern Mind: A Tampa Case," in Jerrell H. Shofner and Linda Ellsworth, eds., Ethnic Minorities in Gulf Coast Society (Pensacola, Florida: Gulf Coast History and Humanities Conference, 1979). 25-30; "Italians and the Tampa General Strike of 1910," in Pozzetta, Pane e Lavoro: The Italian American Working Class (Toronto: Multicultural History Society, 1980), 29-46.

2. Personal letter to author, Paul Avrich, October 6, 1977. 
Selected Listing. L'Unione Italiana Library, Tampa, Florida. Located in Special Collections, University of South Florida Library. Tampa.

1. Setenta dias en rusia: Lo que to pienso. n.d., n.p. marked. International Library. New York.

2. Ivanoe Bonomi. Le vie nuove del socialismo. Milano: Remo Sandron, 1907.

3. Antroposofia-di Bartolomio Giaroli dedicata alle società operaie, n.p., 1883. comes from the pages of La Questione Sociale.

4. In memoriam. Voltarine de Cleyre. Chicago: n.p.. June 20, 1912. A book of radical poetry.

5. Pamphlet, Biblioteca Socialista: No. 5, Anarchica. Includes:

P. Kropotkine, Rapporti al Congresso di Parigi.

L'organizzazione della vendetta chiamata Giustizia.

W. Tcherkesoff, L'anarchia e la chiesa.

L'evoluzione recente fra $i$ socialisti di stato.

6. Pamphlet. Welly Roussel, La ribellione. Roma: F. Serantoni. 1905. A short play.

7. Pamphlet, Eliseo Réclus, Teoria della rivoluzione. Roma: F. Serantoni, 1905. Parts of the series, Biblioteca Popolare Educativa.

8. Michele Bakounine. Dio e lo stato. Firenze: G. Nerbini, 1903.

9. Pietro Kropotkine. La scienza moderna e l'anarchia. Ginevra: Risveglio, 1913.

10. Erckmann-Chatrian. Storia d'un uomo del popolo-ovvero: La rivoluzione di parigi nel 1848. Milano: Casa Editrice Sonzoguo. n.d.

11. Il pensiero, revista quindicinale. Year II. February 1, 1922, no. 3. (Under the auspices of the Società Unione Italiana.)

12. Gaetano Salvemini, La dittatura fascista in Italia.

13. Carlos Malato, La gran huelga (Horrores del capitalismo). Madrid: F. Sempere y Compania. n.d.

14. Pietro Gori. Opere, Vol. X. Conferenze politiche. Spezia: Cromo-Tipo "La Sociale," 1912.

15. Il carroccio (Italian Review). May 1917.

16. Giovanni Grave. La società al domani della rivoluzione. Prima traduzione italiana di G. Ciancabilla. Paterson, New Jersey: 1900.

17. Eduardo Drumont, Socialismo cattolico. Napoli: Società Editrice Partenopea, 1911.

18. Salvatore Chimenz, Cuor di samurai. Yokohama, 1914. A novel.

19. Giovanni de Nava. Musolino: Il bandito d'Aspromonte. Firenze: G. Nerbini, n.d. A novel.

20. Armando Borghi. Mussolini in camicia. New York: Edizioni Liberari. 1927.

21. Pamphlet, Liugi Galleani, La fine dell'anarchismo?, n.p.. 1924. Letters from Cronaca Sovversiva.

22. Pamphlet, Il canzoniere dei ribelli. Published by Cronaca Sovversiva, 1903. Barre. Vermont. A collection of poems by P. Gori, D. Zavattero, A. Panizza, L. Molinari. 
23. Giuseppe Romano-Catania. Filippo Buonarroti: Notizie storiche sul comunismo. Palermo: Alberto Reber. 1898.

24. Gaspare Nicotri and Franco Nicotri, Freedom for Italy!' New York: ItalianAmerican Press, 1942.

25. Augusto Villa. Le religioni e la scienza. Milano: Carlo Polno, n.d.

26. Armando Borghi, Mischia sociale: da . . alla Cooper Union. Introduction by Errico Malatesta. Published by L'Adunata, ca. 1927.

27. Matteotti: Fatti e documenti. Toulouse: Société Méridionale d'Impression, 1926.

28. Pietro Gori, In difesa della vita. 2nd edition. Roma: F. Serantoni, 1905. Conference, 18 January 1904. Messina.

29. Luigi Fabbri, L'inquisizione moderna. Roma: F. Serantoni, 1904.

30. Eduardo Milano, Primo passo all'anarchia: Dedicato agli oppressi di tutto il mondo. La Spezia, 1905. Part of Biblioteca de Liberatio, no. 4.

31. Luigi Goretti, La Cirenaica. (L'Italia non poteva lasciarsi imbottigliare nel Mediterraneo.) Roma: Italo-Irlandese. 1912.

32. Ludovico Caminita, Che cosa è la religione. Patterson. N.J.: Libreria Sociologica, 1906.

33. Errico Malatesta, L'anarchia. Part of Biblioteca Libreria del Gruppo L'Alba, Buenos Aires: n.d.

34. E. Malatesta, Fra contadini: Dialogo. Published by G.S.S. di New York: Beraglia Press, 169 Mulberry Street, n.d.

35. E. Malatesta, Al caffe: Conversazioni dal vero. Roma: Tipografia Industria and Lavoro, 1905. Part of Biblioteca Sociale, No. 1.

36. Pedro Esteve, Socialismo anarquista. Paterson, New Jersey: Imprenta de El Despertar, 1902.

37. Tullio Martello, Storia della internazionale. Napoli: Giuseppe Marghieri, 1873.

38. Massimo Gorki. In America. Roma: Enrico Voghera, n.d.

39. Parola d'un ribelle, n.p., n.d. Inscribed, Dono di Alfonso Coniglio, 22 Ottobre 1932. Stamped, Libreria Sociologica, Paterson, New Jersey.

40. Pietro Gori, Le difese. Spezia: La Sociali, 1911.

41. Pamphlet, Biblioteca Popolare Economica, Marx-Engels, Pagine Socialiste. Genova: Libreria Moderna, 1908.

42. Pamphlet. Saverio Merlino. Perchè siamo anarchici? Buenos Aires: Libreria Sociologica, 1900.

43. P.J. Proudhon, De la creación del orden en la humanidad o principios de organización polótica. Madrid: T. Sempere, n.d.

44. Copies of L'università popolare, 1901, 1902, 1903, 1904, 1905, 1907, 1908, 1909. 1911, 1913, 1914. Directed by Luigi Molinari, Milano. Articles by Carlo Cafiero.

45. Luigi Galleani, Aneliti e Singulti. Newark, N.Y.: n.d. Biblioteca de L'Adunata dei Refrattari.

46. Gaspare Nicotri, Dalla Conca d'Oro al "Golden Gate": Studi e impressioni di viaggi in America. New York: Canorma Press, 1928. 
47. Pietro Kropotkine, La grande rivoluzione. 2 vols. Ginevra: Edizione del "Risveglio," 1911.

48. E. Malatesta, Scritti, vol. 1, "Umanità nova." Ginevra: Edizione del "Risveglio," 1934. Preface, Luigi Fabbri.

49. Max Nettlau, Errico Malatesta: Vita e pensieri. Con prefazione di Pietro Esteve. New York: Casa Editrice "Il Martello," n.d. [1922].

50. Edmondo de Amicis, La maestrina degli operai. Milano: Fratelli Treves, 1908.

51. P. Gori, Prigioni: Versi. Spezia: Cromo-Tipo, 1911.

52. Gaspare Nicotri, Storia della Sicilia nelle rivoluzioni e rivolte. New York: Italian Publishers, 1934.

53. P. Kropotkine, Parole d'un ribelle. Paterson, New Jersey: Gruppi i Risorti e Verità. n.d.

54. P. Kropotkine, Le memorie di un rivoluzionario. Milano: L'Università Populare, n.d. Inscribed, A. Coniglio.

55. Armando Borghi, Errico Malatesta in 60 anni di lotte anarchiche. Paris: Sébastien Faure, 1933. With photos of Malatesta, Galleani, and others.

56. Augusto Bebel, La donna e il socialismo. Milano: Remo Sandron, 1905. 